\title{
Making room for change: Spatial tactics and the micropolitics of inhabiting organisational space
}

Rune Thorbjørn Clausen, assistant professor, Department of Political Science, Aalborg University

Kasper Trolle Elmholdt, assistant professor, Department of Political Science, Aalborg University

Literature on organisational space has pointed at the political nature of space. In this article, we explore the relation between the physical space of organisations and change. Through a case study of a media company that successfully designed a new headquarters with the aspiration to become an open, coherent and transparent organisation, we describe and analyse the micropolitics of organisational space. Using the concept of 'spatial tactics', we explain how initial intentions with the building design were resisted and renegotiated at the micro level as employees began inhabiting organisational space, by which, we argue, room for change was made. The study contributes to the literature on space and organisational change by providing an empirical account of how spatial tactics matter for making buildings work in change initiatives.

Introduction

\begin{abstract}
"It was extremely important not to water down the existing culture, identity and soul of the various publications. However, we believed the gains to be substantial in terms of bringing the organisation out in new settings, galvanising them. There are quite a lot of skeletons in the closet when you live in the same place for over hundred years." (Chief Financial Officer, AM)
\end{abstract}

Since the advocacy for "bringing space back in" (Kornberger and Clegg 2004), space and architecture have received increasing interest in organisation studies (Taylor and Spicer 2007; Dale and Burrell 2008; Van Marrewijk and Yanow 2010). In terms of organisation and politics, architecture and space have also received increased interest as an interesting object of study since managerial and architectural intentions confront the experiences of 
occupants, as they inhabit and 'bring life' to buildings (Latour and Yaneva 2008). Generally, buildings have been argued to be political by design, as they order and transform space and thus, normatively demarcate boundaries of organisation (Lefebvre 1991; Dale 2005; Hernes 2004). A fact Massey (2005) also pointed out when she argued for space being fundamentally political and how space by nature invokes political engagement. For instance, the negotiation and managing of trade-offs between the varying types of purposes of office buildings is an important but also contestable organisational and managerial issue (Elsbach and Bechky 2007). Thus, built spaces are purposeful and political as they normatively enable and legitimate or constrain organisations. In continuation of this, a body of literature has set out to explore how architecture is used to facilitate organisational change (Lancione and Clegg 2013; Van Marrewijk 2009; Våland and Georg 2018). As any other change effort, changes in architecture are likely to threaten the status quo and turn into a political activity, in which different interests become visible and in need of reconciliation (Morgan 2006). Yet, while much attention has been on how buildings are used for shaping organisational processes of change (Holloway Cripps 2013; Van Marrewijk 2009), the focus on the tactical and political work taking place at the micro level when inhabiting new buildings has been scant (Munro and Jordan 2013; Courpasson, Dany and Delbrige 2017). By drawing on de Certeau's (1984) concept of tactics, we add to the literature on organisational change and space by explaining how the micropolitics of spatial tactics matter in 'making room' for strategic change. To guide this aim, we formulated the following research question: What role do spatial tactics play in using buildings in organisational change?

In order to address this question, we draw on a case of the relocation of a major Danish media organisation (AM) into a new corporate headquarters. The organisational change also involved a radical architectural change from a building containing a closed office layout characterised by many 'back regions' and demarcated subunits into a new open office layout characterised by many 'front regions' and the absence of physical boundaries between subunits. The building was purposefully designed to support the strategic change project of transforming the company into a modern, coherent, transparent and visionary organisation. The opening quotation by the CFO of our case organisation illustrates the politics of space by touching upon the issue of "transforming the several into one" (Latour 2003, xx) and the movement from a multitude of distinct units towards the creation of a more cohesive unity, a movement which may end up producing a 'we' and a 'they' (Latour 2013). In this article, we explore how the politics of space empirically shows itself and unfolds on a micro level as the effect of a design strategy informed by bringing the organisation "out in new settings". To this end, we study the confrontation between design policy and usage and we address the topics of space, organisation and politics by focusing on the corporate building as a medium for change.

In our analysis, we illustrate how the design of the building from back- to frontstage involved a 'politics of openness' that aimed at achieving purposes of symbolic and instrumental character in the sense of making the organisation transparent and more collaborative across departments. Then, we unfold the politics of spatial tactics taking 
place as employees, in accomplishing everyday work, start enacting and resisting the new building and the open setting. We suggest that the building 'makes room for change' but as an effect of the spatial resistance and settlements as performed and negotiated by those consuming and inhabiting the building. We find that the politics of openness includes and excludes not only certain activities but also belongingness, which we illustrate through two types of settlement dynamics concerning 'work' and 'identity' issues. Here, we understand the notion of 'settlement' in its double meaning, pointing to the dual and reciprocal effort of inhabiting space while negotiating and making compromises in and with space.

The article proceeds as follows. We start by outlining our theoretical backdrop on organisational change related to space and resistance and outline our 'tactical' approach to questions of change, space and micropolitics. We then present the methodology followed by our empirical analysis. Finally, we discuss the findings and position of our contribution in the literature on organisational change that relates to space and politics.

\section{Space, organisation and change}

Since the spatial turn in sociology (Halford 2004) began migrating into organisation studies, organisation space has gained further momentum and currency. Generally, the role of space, architecture and materiality has however remained under theorised in the change management literature (Leonardi and Barley 2008: Lancione and Clegg 2013). The emphasis has been on conversational perspectives and prescriptive models in the mainstream literature (Elmholdt, Clausen and Madsen 2018). Yet, a number of studies do point at the role of architecture and space in facilitating changes in organisational identity, strategy and legitimacy (Lancione and Clegg 2013; Holloway Cripps 2013; Van Marrewijk 2009; Våland and Georg 2018; de Vaujany and Vaast 2013). For instance, de Vaujany and Vaast (2013) relate corporate architecture to questions of identity and legitimacy and show how changing the former NATO headquarters into a university allowed different organisational legitimacy claims, which were entwined with and animated by the building and its spatial legacy. They show how the implicated actors were managing organisational legitimacy by appropriating the building to appear as a modern university. As de Vaujany and Vaast (2013) note, architectural changes are inflected by "unintended consequences of changes in organisational space” (p. 728). Likewise, Våland and Georg (2018) address how space and identity merge in an architectural and organisational process of change. Illustrating how the design of a reception counter in a municipality demarcated differences in identity between staff and citizens, they suggest the notion of 'spacing identity', in which affective and material entanglements operate. Van Marrewijk (2009) argues for the role of architecture as a physical and symbolic embodiment of corporate strategies, making a call for involving managers in the design process. In a study of how a business school aimed to change identity through a new facility, Lancione and Clegg (2013) advocate for the importance of micropolitics in making identity transitions through the use 
of buildings. Lancione and Clegg point at the micro level political negotiations and suggest that an important part of change is network maintenance in which relational practices and technologies that makes up the organisation are maintained during change. Managing change becomes a matter of being aware of the unconscious background of organisations where things are trying to be kept in place or maintained in order to work (Lancione and Clegg 2013, 138). In other words, these actions may be considered unwanted, but they are inevitable and important to the change process (Lancione and Clegg 2013).

Relating to the work of Lancione and Clegg (2013), another body of research on organisational change revolves around the notion of resistance (Dent and Goldberg 1999; Thomas et al. 2011). As Thomas and Hardy (2011) argue, resistance has been conceived very differently. While one part of the literature has been 'demonising resistance' and individualising change (Dent and Goldberg 1999) as something to overcome, another part embraces resistance as a signal of receptiveness to the request for change, yet seeking some accommodation of the change effort (Ford et al. 2008, 373). In contrast, Thomas and Hardy (2011) suggest a discursive approach to resistance where resistance is co-constitutive to power, which they suggest is an evitable part of change. Resistance becomes creative and generative and can be considered as a 'politics of meaning' where leaks of meaning are exploited to create accommodations of change (Thomas and Davies 2005). Courpasson et al. (2012) point to the political nature and role of 'objects of resistance' and how they may be mobilised to achieve a change effort. These areas of literature indicate the productive and micropolitical aspects of space and resistance in change efforts and sensitise us towards the role of tactical work in accommodating spatial and organisational change. In order to advance this understanding further we turn to the work of de Certeau and his notion of tactics as creative acts of resistance.

\section{Micropolitics of spatial tactics}

An important argument in the literature on organisational space is not to treat space as a passive and neutral container but rather underscore the generative aspects of organisational space (Kornberger and Clegg 2004). This brings forth a need for studying not only spatial layout, scales, decor and building shape but also how the social, personal and professional spaces are experienced and imagined by the actors using the physical setting (Taylor and Spicer 2007). For example, when zooming in on the 'spatial tactics' of street performers in public spaces, Munro and Jordan (2013) reveal the politics of space as artists negotiate spatial boundaries to demarcate a hybrid workspace in the public domain. In this regard, spatial tactics are political in the sense that they are to negotiate order by drawing new boundaries. Paraphrasing de Certeau (1984, xix) the term tactic designates 'a calculus' that cannot count on any proper fixed spatial or institutional localisation and it is in that sense different to what de Certeau describes as the logic of strategy. However, tactics do not operate voluntarily as they are always asserted and preconditioned in relation to "the non-autonomy of its field of action" (du Gay 1996, 165). Tactics provide 
sensitivity towards the ways of using deployed by the implicated actors (du Gay 1996) and their ways of trying to maintain or appropriate certain ways of working (Lancione and Clegg 2013). However, to make the physical environment a resource for multiple purposes, spatial opportunities must be seized in situ by tactical navigation (de Certeau 1984). When chance offerings present themselves, a host of successive tactics and pragmatic ruses are mobilised to capture opportunities produced by the occasion or to actively turn particular events into openings by manipulation (de Certeau 1984). Organisational settings are often formal and governed by professional and occupational codes and employees are procedurally kept acting towards shared organisational and institutional goals. The familiarised narratives and rhetorical logic used by occupational groupings are likely to reinforce a hierarchical organisational space (Zhang and Spicer 2013). However, breaches of the proprietary powers do happen and the spatial openings created by the breaches may, if seized, give rise to change (Kornberger and Clegg 2004; Munro and Jordan 2013). Of particular interest is how these 'cracks' (de Certeau, 1984), are turned into a resource for innovation, change and organisational development.

\section{Method}

To provide a rich and concrete empirical account of the micropolitics of organisation space, we apply a qualitative research approach (Denzin and Lincoln 2011). The case for our study is the relocation of a large and tradition-bound Danish publishing company (AM) to a new modern office building. We chose this case purposefully as it represents a 'forceful example' (Flyvbjerg 2006) that enables us to take a particular vantage point for illustration of the general dynamics and types of politics involved in inhabiting and settling in organisation space. In the literature, various analytical approaches to organisational space have been applied either focusing on the materiality of how space is used, how the design of space may reinforce power relations and control, or by focusing on how space is experienced and interpreted by the people occupying it (Taylor and Spicer 2007, 335). In our study, we focus on the third body of research by looking into how employees react to, interact with and enact the new headquarters as they move in. Although buildings come across as fixed objects, we know lots of activities take place within and through them. The problem, however, is how to get past the fixed image of the building and to illustrate the continuous flow that a building always is (Latour and Yaneva 2008). One way is to zoom in on the daily activities and tactics performed by those consuming the building (de Certeau 1984). To this end, we draw on a combination of data collection techniques to capture our empirical account from semi-structured interviews, observation notes, documents and various objects (Silverman 1993). We apply a visual ethnographic strategy (Pink 2007) as a framework for guiding our data collection on how participants make sense of the built environment. To understand motives and strategies behind the relocation as well as the architectural design, we interviewed a member of senior management representing the organisation as a client as well as the responsible 
architects. To understand user perceptions and experiences with the building, we selected 12 employees spanning departments, professions and hierarchies to ensure variation. We carried out two rounds of interviewing and had participants take photos before the second round, which produced 180 photos in total. We asked the respondents to take pictures of places in the building that had either value for them or where the building was of no value. It could be concrete and material dimensions of the building or symbolic and social aspects enabled or constrained by the building. Whereas round one took place just after moving in, round two took place one year after occupancy and followed up on the photographs. Interviews were all semi-structured, audio recorded and transcribed verbatim afterwards (Gubrium and Holstein 2002). Collected photos were all organised into themes with the support of interview transcripts, observational notes and documents such as architectural drawings and marketing materials. In total, three main themes emerged from the data concerning identity construction, perceived image and work activities (function/performance). This formed the basis for selecting events in our case that illustrated the politics of spatial change.

The case

\begin{abstract}
"Many reasons supported the idea of moving to a new 'lawn'. Not only the fact that the former building was dilapidated but importantly also the fact that we wanted to send a new and different signal to both employees and the outside world: to turn it all upside down; to change the organisation; to challenge it; and to get rid of old dogmas." (CFO)
\end{abstract}

The case is the relocation of the corporate headquarters of AM, a Danish media company housing approximately 600 employees. AM is a historic and tradition-bound organisation that for over 100 years had its former headquarters located in the suburbs south of Copenhagen. Around the turn of the millennium, AM began a process of modernising the organisation making it an innovative media company ready for the digitalised era. This included both the issue of facility management and the matter of organisational development and change. AM consists of a series of publications, and in the former headquarters the various editorial offices of each of the publications were "ruling their own small kingdoms" both territorially and culturally, as one employee put it. Another employee, describing the feeling of walking the corridors of one of the editorial offices, supports this:

\footnotetext{
"When walking the corridors at editorial office ' $X$ ' you had the feeling of being in unknown territory - you were entering another world, to which you had no relation. You did not think of it as a part of AM but rather as a standalone magazine."
} 
Consequently, this produced silo mentality resulting in limited communication and crossboundary collaboration between editorial teams leading to decreased organisational cohesion, a development the management was keen to change while still keeping intact the cultural distinctiveness and identity of individual publications. In addition, there was the issue of making the image of the organisation, as a modern and professional business, stronger in the eyes of external stakeholders. Altogether, AM believed this could be done more easily and effectively if the organisation was brought out in the open both organizationally and architecturally speaking. With this objective in mind, AM together with the architect began defining the design brief, which kicked off a comprehensive end-user participation process, in which employees iteratively participated closely with the architects in developing the design. Informed by AM's demands and needs, the design intention focused on bringing the organisation architecturally 'out in the open'. Having been housed for over 100 years in an old opaque red brick building consisting of long, narrow corridors with offices on a string, AM moved in 2009 to a transparent glass building designed with a large atrium surrounded by open and flexible working spaces. An office building that has proved to be a huge success. The Danish Association of Architectural Firms has, among others, highlighted the building as an example of architecture that creates value. Likewise, the design has been recognised by the City of Copenhagen as great architecture. This case works as the backdrop for our study, in which we do not question the value and success of the building but rather we explain the role of micro level politics of inhabiting organisation space.

\section{Analysis}

Starting with a comparison of the layout of the two headquarters, we show how the move is an example of relocating architecturally from 'back- to frontstage'. Whereas the increased number of front regions in the new headquarters inform and frame AM as a modern, open and innovative type of organisation, the character of the front region at the same time fixes a spatial spell (Goffman 1974) over the place, which, at the everyday practical level, creates resistance. The shift from back- to frontstage disrupts the status quo and the negotiated order requiring the organisation to engage in spatial renegotiations of order. By studying how AM architecturally turns the organisation from 'back- to frontstage', we explore the politics of openness and the spatial tactics involved. The analysis consists of three main parts. Part 1 analyses the strategy and design policy of the building by describing and visualising the locating from back- to frontstage. In the second and third parts, we zoom in on the tactics and focus on two central dynamics of inhabiting and consuming organisational space, which we illustrate by departing from photos taken by the respondents of our photo-ethnography. While Part 2 concerns the character of work and the importance of daily activities, Part 3 concerns the nature of identification and construction of a sense of belonging. Both, we argue, illustrate the dynamics of 'settlement'. By using the notion of settlement, we wish to emphasise the double meaning of the word, which 
points to both inhabiting organisational space and the process of negotiating and making spatial compromises. We believe this double meaning of the word 'settlement' is illustrative and explanatory for the relation between organisation, space and politics.

\section{Part 1: From back - to front stage}

"The starting point for the construction was a triangle with curved fronts and a huge open space in the middle. It's not the ideal shape for designing workspaces. Lots of square metres are lost on office aisles. On the other hand, we know how fantastic it is to be in the building - due to the shape, it has intimacy as well as openness; it has small closed areas as well as large open spaces." (Senior architect)

The contrast described above is the effect of the design solution to AM's wish to bring out in the open the various editorial teams and departments while keeping their core identity intact. The new building was architecturally very different to the old one. As illustrated in the six simplified layouts (Figure 1), one main contrast between the two buildings was in terms of back and front region areas. The former domicile (Diagram 1) had a small reception area on the ground floor and appeared closed and opaque from the outside. When visitors arrived at the reception they were led towards the staircase and elevators. When walking the corridors, closed doors protected employees in their backstage regions of the organisation.
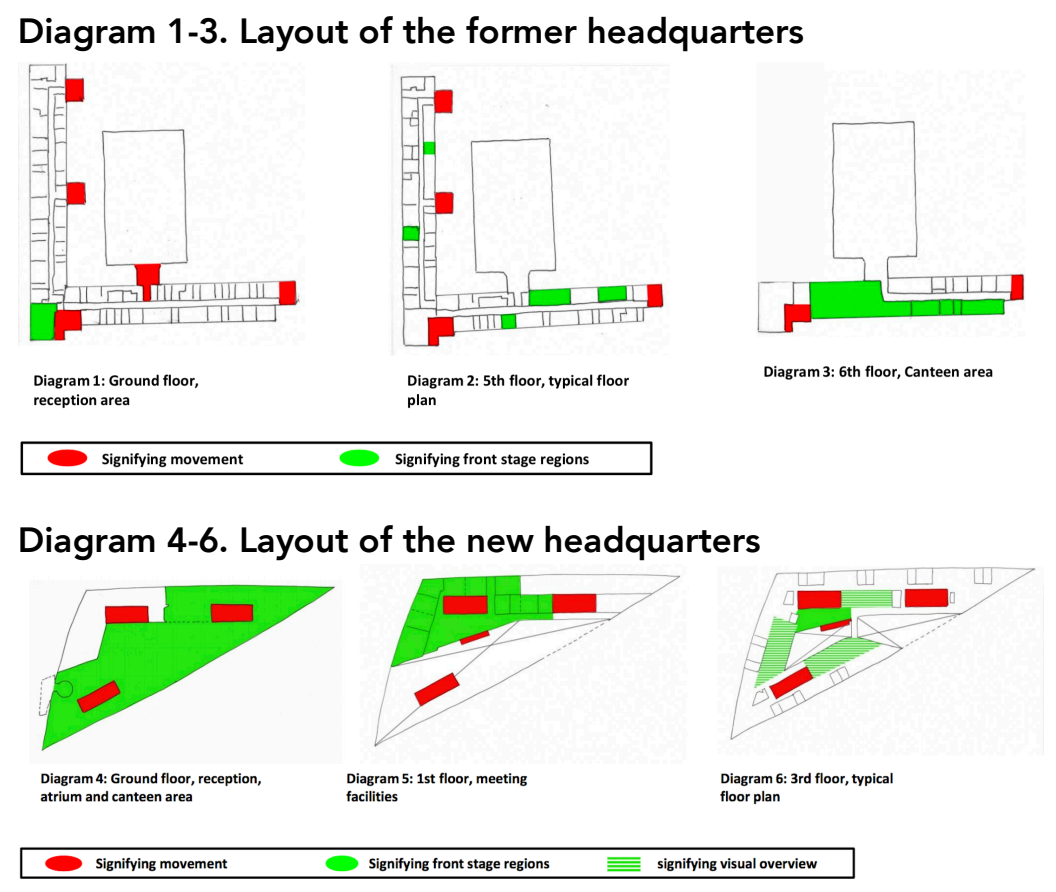

Figure 1. Simplified layouts (Diagrams 1-6): the green colour signifies frontstage regions and the red colour signifies the staircase and elevators. 
In contrast, the ground floor of the new domicile (Diagram 4) is almost entirely a frontstage region supporting the idea of making the organisation more transparent. In continuation of the reception area, one is led into a large and open atrium with the canteen on the left as an integral part of the ground level (in contrast to Diagram 3, in which the canteen is isolated on the sixth floor). Office spaces, meeting rooms, lounges and quiet rooms in varying spatial dimensions encircle the fan-shaped atrium - from closed to open. If taking the staircase, one is, due to the terracing and retreating floor levels, invited to look into the backstage regions of the editorial groups while climbing the stairs upward. If taking the elevator, such peeks are also allowed when using the lounges in front of the elevator shaft at every level (shaded green in Diagram 6). In contrast to the former domicile, few choice points such as corridor intersections and door openings characterise the layout of the new domicile. The ambition was a high degree of architectural legibility, and to create many gathering points where employees can meet and interact. As an employee notes, "the number of colleagues you meet and interact with is multiplied by 100 compared to the former location". The design of the new building provided the physical blueprint for the ambition of bringing people together. To many of the employees this indeed was the case, as an employee working in a support function notes:

"There is a much stronger feeling of unity, between magazines. I used to be intermediary but now they just meet, walk by each other and set up appointments etc. It makes my job much easier in all aspects; that we think 'us' and not 'me'."

While the respondent describes how the shift from back- to frontstage provides the organisation with the opportunity to have smoother cross-boundary collaboration, the character of the frontstage design also reflects a new image of the organisation as modern and professional. As an employee working within sales says: "when I book meetings people come here, they want to see this temple. I'm proud to invite them, which I never did in the former building - I'd rather go to them". However, the employees and management are, as well as the architect, aware of the fact that the trilateral site "with an atrium in the middle, around which everything else then has to function" comes at a cost (CFO). For instance, the openness and high movement frequency also has downsides as described by an editor: "you feel exposed down there (the atrium). You are afraid that people hear what you say, so you consider the type of meeting or talk you engage in". This illustrates the presence of competing matters of concern, which brings to the fore the need for negotiation of 'trade-offs'. The relocation makes certain activities possible while others are constrained, and in this setup, the organisation and its members must settle. This is complicated by the fact that the spatial layout is a sort of Janus face - what may afford meaning and value to some employees are constraints to others -requiring organisations to continually fine-tune how it exploits and explores its workspaces. 


\section{Part 2: Work settlements}

With the relocation, taken for granted organisational orders, routines and practices are interrupted for either good or bad. In the example below, it becomes clear how spatial tactics are performed to renegotiate the organisational order. In the new building, various tasks and activities are taking place simultaneously: writing articles, various meetings, advertisers pay visits, photo shoots, styling, interviewing, editing, eating lunch and using the bathroom, etc. A fundamental work task in a media company is photo editing. This task is embedded in a web of relations and concerns that are in play when carrying out such mundane everyday work. In the new building, the negotiated order concerning this particular task had to be renegotiated as an implication of the openness of the new spatial design, in which employees are differently placed.

In the former building, it was possible to completely black out the rooms when one was editing photos due to the spatial layout and closed exterior. The new building and office design challenge this specific working requirement. The idea of openness meant that photo editing was to take place in the very neat and minimalistic open office space. It was not possible to black out a room or go elsewhere, which caused difficulties in performing the primary task of the photographers. Consequently, as an interim solution, employees began setting up umbrellas to shield the sun when editing photo material at the workstations (as illustrated in the right photo in Figure 2). An employee working with layout explained how they tried to bypass the problem with the new design by putting up umbrellas: "the sunlight that enters through the crack in the shutters on the windows finds its way to our screens. It is not optimal, but the umbrellas take away the worst light".
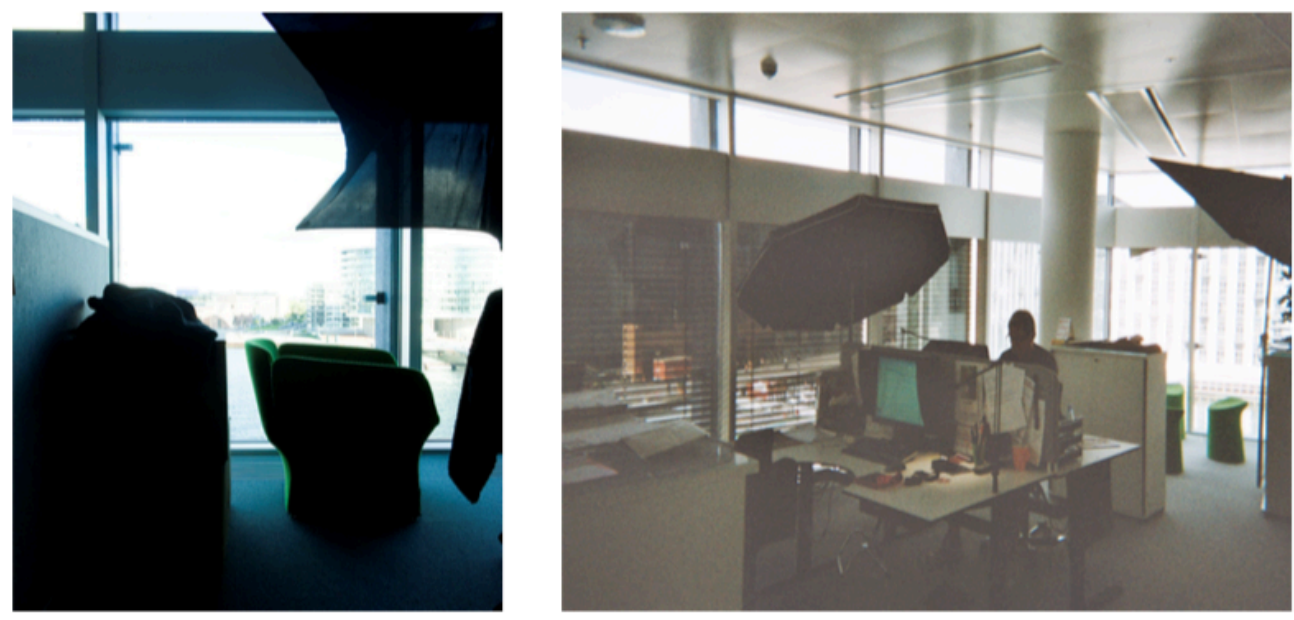

Figure 2. Pictures of the use of umbrellas to shield social contact and sun light

This was at odds with the 'politics of openness' as declared in the design policy, which implicitly required neat workstations without messy arrangements. The umbrellas, however, became an artefact symbolising the professionals working with photography and 
editing. According to the professionals working with editing and photography, the best solution had been to have dark rooms or more advanced methods for shading their screens. Over time, the umbrellas came to work as an agreement, as a photographer explains:

"It is a big issue (the sunlight) but we solve it this way. The problem is that we cannot just black out the room because then somebody complains about us shutting the natural light out and then it's kind of a compromise with the umbrellas."

The photographers did, however, not only use the umbrellas for editing. The open office made it difficult to demarcate private spaces; hence, at times certain spaces were seized for other purposes than the functional aspects of work (illustrated in the left photo in Figure 2). In this photo, the same photographer found that the umbrella could perform other functions than allowing him to achieve high quality editing. He used the umbrellas that were to shield computer screens from the sun to shield himself from other people, thus creating a backstage within the open office. Due to the character of the frontstage region, he enjoyed withdrawing into this self-made place of 'refuge'. In order to achieve work, the editor had to be able to edit images, which is a primary job function but in addition to this he also enjoyed being able to withdraw to talk and socialise with close colleagues and to have time on his own. Using the umbrella made daily work life possible in situations where the building did not support it due to sunshine or too much traffic in the open space. In turn, the installation of umbrellas enabled multiple purposes, but their use was not uncontested by other professionals in the office. For instance, other professionals sitting in the open office in other functions enjoyed the sunshine and in particular the open view into the harbour, as described by a journalist: "well, yes. If you just look out, then you are fresh again. It is so nice, and something of great importance for me in my everyday work life". Putting up umbrellas was interrupting this aspect of the building and was to some extent controversial, however, the umbrellas were, after a while, accepted as an 'object of work'.

In sum, the re-ordering of the office was justified by the characteristics of the work task that provided an occupational mandate for the photographers to put up umbrellas in the office space. While this mandate was to some extent considered legitimate, the activity nonetheless was also at odds with the design policy and constraining some of the other employees. The umbrella initiative also reinstated professional work differences in the office. Hence, the building may from afar look as a physical and fixed object, but its meaning and value may change as boundaries are drawn and some activities are included or made possible while others are excluded or constrained. By drawing new task related boundaries, employees, in our case, learned to settle in the new building as well as to settle various trade-offs. 


\section{Part 3: Identity settlements}

As the example above illustrated, spatial tactics were mobilised by work arrangements and the need to perform job tasks. Below, we illustrate how inhabiting the building not only asserted tactics originating from a need for 'work settlements' but also from a need for 'identity settlements'. Below, we zoom in on another concrete episode, which illustrates the fundamental aspect of belonging and identification. Taking the photos (Figure 3) as a starting point, we illustrate the web of relations and concerns that are also at play in organisation space as issues of identity and the ability to align organisational identity, image and culture are disrupted by the relocation and organisational change effort.
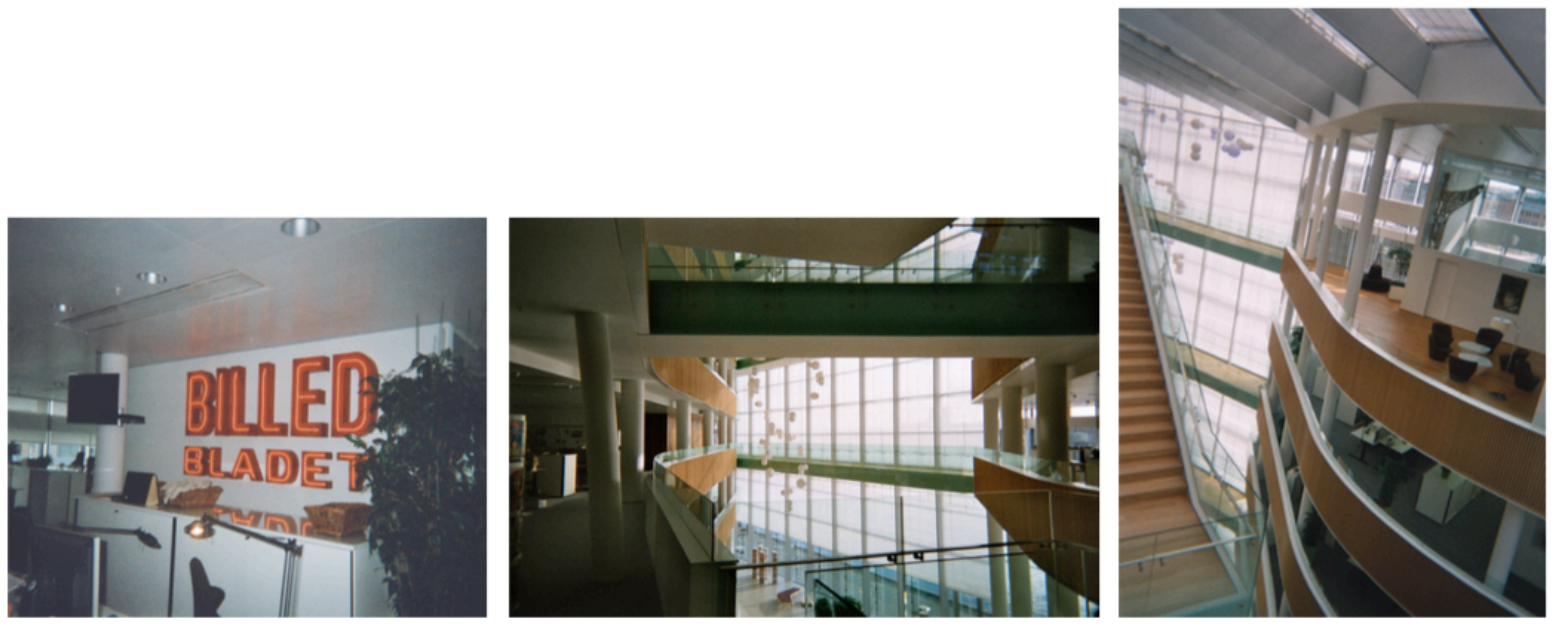

Figure 3. Pictures of a neon light of a magazine title, view into the atrium and view to the owner offices.

The three photos in Figure 3 have been taken by three different employees and depict the complexity and controversy associated with moving from back- to frontstage as part of the organisational change. As already stated, a main strategy for moving was to be located in a building that supported the new identity as a coherent and modern media company. The photo in the middle illustrates what several of the respondents agree upon, namely how the openness and the view into the offices located around the atrium at the centre of the building connect the many subunits, which have resulted in a feeling of unity and being one corporate brand. When describing the reason for taking the photo the respondent explains how the openness has enabled not only more contact with 'outsiders' from other departments and magazines but also respect for their work and who they are due to the fact that you "see what goes on". Another employee describes a similar feeling when contemplating how "it's probably the AM 'spirit' that has begun to take over - the fact, that we actually work in the same place". This was not a matter of fact in the former building that incited fragmentation due to the spatial layout. The awakening of the 'AM spirit' is likely an effect of the architectural design, which is supported by another respondent who attributes the change to the layout of the building. The breaking down of 
corridors and walls help facilitate this by the politics of openness. An employee describes how the stronger sense of community has fortified the identification to AM as a corporate brand rather than working solely in the sub-brands (publications), which was one of the main purposes of the relocation. The following account illustrates a very concrete and simple but nonetheless valuable effect of this:

"When we are sent to take photos of a particular event, then we do it for
each other now. We do not need to send three photographers each repre-
senting their own magazines. It is far more frictionless than ever before."

However, the feeling of cohesion is not only facilitated by enabling proximity and removing physical boundaries leading to more frequent collaboration but also by the symbolism of the building, which the third picture in Figure 3 depicts. It shows the office of the owners at the top floor. A totem pole is visible behind the glass wall of the office and outside in the waiting area are placed some cultural artefacts. The employee took this picture as it reminds her of the history and legacy of the company, but also as an illustration of how "management is far more visible due to the layout of the building. We see them more often. We are reminded of the fact that they are made of flesh and blood. That matters a lot". This makes the employee more prone to identify with the organisation. The symbolic nature of the building is likewise helping achieve 'identity settlements' in terms of being proud of their membership. As the employee notes:

"You are reminded of what this is all about: we are a large company. Lots of money, lots of customers. You are proud when guests are on visit, and they see it. Many places in the building reflect this."

What the employee explains here is how the ensemble is reconfigured and everyone is reminded that they are one. The unification of the office design and the majestic image of the building may produce a sense of belonging; however, it is not without controversy. To some employees, the openness and feeling of unity has a counter effect in regard to remaining distinct. As an employee describes it:

"We wanted to put up posters in our department to signify ourselves. They were up for a short period of time before it was reprimanded and taken down. It is not possible to recognise us, which I think is a shame. It could be any type of company that lives here."

As the quote indicates, the politics of openness brings identity at stake concerning the fundamental question of who 'we are'; one company and not the many. This challenged, to some degree, the established identities related to units and magazines. Here, managerial decisions and facility management concerns overruled identity concerns, which had the 
effect of making some of the inhabitants feeling invisible. This was, in some cases, handled through acts of resistance and tactics that seized space to renegotiate order thereby making a place for belonging. The picture of the red neon light illustrates the 'victory' and identity settlement that one of the departments had. The employee who took the picture is from one of the well-established magazines that had its identity challenged by the relocation. It is a neon light of the name of the magazine and the artefact is a highly historic and (in)famous family gem and symbol from the former office. When the light is on, you are able to see the sign from afar due to the openness of the building, which makes it an important marker and object of demarcation. The sign worked as an instantiation of old boundaries. While this was important to the employees from this magazine, to other employees and departments, this is not important at all. As an employee notes: "we did not have any special kind of memories or 'gems' that just had to come with us to the new building. To be honest, I do not care at all'. For the employee who took the picture, the sign had importance because it afforded the possibility to signal to the rest of the organisation who inhabited this particular area of the office landscape but also in relation to their sense of self in the organisation.

What the pictures and episodes in this part illustrate is how the same space (the open atrium) makes place for different ways of 'identity settlements' containing various trade-offs. For some, demarcation matters, for others not. For some, the politics of openness makes invisible, for others it makes visible. Here, we see how the performed spatial tactics and the level of compromise between involved actors define the outcome.

\section{Discussion}

Through the analysis, we unfold how the architectural design and layout of the new building enact a 'politics of openness' by bringing things to the front, providing valuable opportunities as well as challenges. The design policy supports the strategic vision of creating a new modern identity for AM, in which individual publications were gathered in one united media house. Following the analysis, we point out some theoretical implications. Our analysis has shown how the politics of openness promising one united company produced both opportunities and difficulties concerning valued differences. The order proposed by the open design was, to some degree, resisted in parts two and three through renegotiation of organisational orders. Our findings resonate well with our inspiration from de Certeau (1984) and the way he contrasts the logic of 'strategy' with the logic of 'tactics'. Accordingly, "strategies conceal beneath objective calculations their connection with the power that sustains them" (de Certeau 1984, xx). In our case, we consider these strategies to be visible in the building plans and design policy that suggest an open and united mode of organising. As du Gay (1996) notes, "strategy proceeds as if it has its own 'God's eye view' from which it can reflect on the everyday. It involves a victory of place over time, and a mastery of places through sight" (p. 89). In contrast, tactics introduce "movement into the system" (de Certeau, 1984, xx), which is exactly what, for example, 
the use of umbrellas and the red neon sign reflect. We find that the strategy of the design policy creates boundaries that include and exclude certain actions and activities but also issues of belongingness and identity. Hence, the organisation's change effort is political. Yet, through local tactical and spatial work, employees creatively invoke movement and repurpose and re-order organisational space in order to settle in.

We suggest that the issues of work and identity settlements are micropolitics in action that have to do with renegotiating the composition of the 'we' (Latour 2013) and it has to do with redrawing boundaries that create certain inclusions and exclusions. Our study points towards the importance of paying attention to the micro level spatial politics when buildings are used for driving organisational change. The new building 'makes room for change' in the sense that it facilitates an arena where managerial intentions and everyday practical concerns of employees can intertwine, align, be resisted and transformed. This process invokes resistance and negotiations over meaning (Thomas and Davies 2005) as illustrated in the two types of settlements. Here, we highlight the importance of resistance during change, which describes the situated and tactical work employees perform as they enact the new workspace and effectuate change transformations. In this regard, our study provides two main contributions, one within the general literature on space in organisations and the second within change management.

First of all, our analysis contributes to the literature on organisation space and change. This literature has mainly been focusing from a macro perspective on how organisational processes of change involving architecture are used for identity change. Hence, the focus has only, to a limited extent, been on the actual use of space. The new building made use of large, open and flexible workspaces compared to the former building as illustrated by the comparison of spatial layouts. As our account illustrates, the design programme offers various affordances that both enable and constrain, for instance among and between employees working with layout and those with other professional identities. We argue that design policies are highly controversial but productive at the micro level and they are up for negotiation between organisational members as they inhabit and appropriate the building. This is illustrated in our case by how some employees engage in an effort to repeal the spatial spell cast by the character of frontstage region while others embrace it as productive (Goffman 1974). In this regard, we add to studies of organisation space by zooming in on the micro-orderings taking place between buildings and their inhabitants. We build on recent empirically grounded research regarding daily spatial practices, by which organisational space is produced and reproduced (Van Marrewijk and Yanow 2010; Munro and Jordan 2013). Our inquiry joins this call by demonstrating how employees settle in by navigating the various tasks that their work environment is comprised of while balancing issues of identification and belongingness. Thus, we contribute to the literature on organisational space and change by showing how spatial tactics redraw boundaries and become micropolitical.

The second contribution relates to previous studies of the role of resistance in change efforts. Resistance to change is a key concept in the literature on organisational change. Whereas earlier studies have conceived resistance with an individual deficit, our 
study extends the studies of Thomas and Hardy (2011) highlighting the creative and productive role of resistance and the role of objects in this process (Courpasson et al. 2012). In our case, we see how spatial resistance evokes redesign, compromises and eventually a settlement by the use of mundane artefacts. We support Thomas et al. (2011) then, who suggest we understand acts of resistance, not only negatively, but also as productive aspects of producing change. The building has proved to be a huge success not despite instances of resistance but because of. In fact, we may see the success of the building as an effect of the many micro-negotiations that mobilise employees to engage in modes of re-ordering as when the layouter re-ordered organisational space by the means of an umbrella. In the situation, the building is repurposed to make the change effort fit the work of professionals working with layout. In other words, the repurposing may not serve as just violating an original intention from the architect or management, rather it is an essential performative part of making the building work and illuminates how space is constantly being made and remade, making the building a moving project (Latour and Yaneva 2008). Whereas previous studies of resistance have often emphasised the discursive aspects of resistance (Thomas and Hardy 2011; Thomas et al. 2011), our study contributes to research showing how resistance to change also involves the use of mundane artefacts. Extending Courpasson et al. (2012) and their focus on objects of resistance in terms of texts and reports, we show how mundane materials such as an umbrella or a sign may settle a micropolitical and spatial negotiation over meaning. In line with literature on resistance as a creative, generative or productive act (Thomas et al. 2011), we suggest that it is by invoking materials and space that resistance is performed, and we may benefit from being sensitive to how space is used to perform resistance and where and how micropolitical boundaries are drawn and redrawn.

\section{Conclusion}

We started out by raising the question of what role spatial tactics play in making room for organisational change. We conclude that spatial tactics become key for making change work, which we have argued have both practical and theoretical implications. Taking a successful building as point of departure, we found that the micro-politics of change-work is important to understand how a building comes to 'work' in organisational change. The success of the building is also an effect of multiple preceding actions and situations, which in our case is illustrated by the underlying spatial tactics performed as inhabitants 'settle' in organisation space. Our focus on the micropolitics of spatial tactics imply the attentiveness towards how 'settlement' is both a matter of inhabiting space and negotiating compromises in and with space, which are heterogeneous and on-going accomplishments involving physical and social arrangement as well as references to occupational knowledge in terms of work characteristics and identity. We believe such focus to be a promising avenue for further research, and we advocate travelling deeper 'into space' in order to explain more thoroughly how to 'make space for change'. 


\section{References}

Courpasson, D., Dany, F., and Clegg, S. (2012). Resisters at Work: Generating Productive Resistance in the Workplace. Organization Science, vol. 23(3), pp. 801-819.

Courpasson, D., Dany, F. and Delbridge, R. (2017). Politics of Place: The Meaningfulness of Resisting Places. Human Relations, vol. 70(2), pp. 237-259.

Dale, K. (2005): Building a Social Materiality: Spatial and Embodied Politics in Organizational Control. Organization, vol. 12(5), pp. 649-678.

Dale, K. and Burrell, G. (2008): The Spaces of Organization and the Organization of Space: Power, Identity and Materiality at Work, Basingtoke: Palgrave Macmillan.

Denzin, N. K., and Lincoln, Y. S. (2011). The SAGE Handbook of Qualitative Research. Thousand Oaks, CA: Sage.

De Certeau, M. (1984). The Practice of Everyday Life. Berkeley: University of California Press.

Dent, E. B., and Goldberg, S. G. (1999). Challenging "Resistance to Change". The Journal of applied behavioral science, vol. 35(1), pp. 25-41.

de Vaujany, F. X. and Vaast, E. (2013). If These Walls Could Talk: The Mutual Construction of Organizational Space and Legitimacy. Organization Science, vol. 25(3), pp. 713-731.

Du Gay, P. (1996). Consumption and identity at work. London: Sage Publications.

Elmholdt, K. T., Clausen, R. T. and Madsen, M. (2018). Seductive Atmospheres: Using Tools to Effectuate Spaces for Leadership Development. Journal of Change Management. Available at: DOI: 10.1080/14697017.2018.1453856.

Elsbach, K. D., and B.A. Bechky. (2007). It's More Than a Desk: Working Smarter Through Leveraged Office Design. California Management Review, vol. 49(2), pp. 80-101.

Flyvbjerg, B. (2006). Five Misunderstandings about Case-study Research. Qualitative Inquiry, vol. 12(2), pp. 219-245.

Ford, J. D., Ford, L. W., and D'Amelio, A. (2008). Resistance to Change: The Rest of the Story. Academy of management Review, vol. 33(2), pp. 362-377.

Goffman, E. (1974). Frame Analysis: An Essay on the Organization of Experience. Boston: Northeastern University Press.

Gubrium, J. F. and Holstein, J. A. (eds.). (2002). Handbook of Interview Research: Context and Method. Thousand Oaks, California: Sage Publications.

Halford, S. (2004). Toward a Sociology of Organizational Space. Sociological Research Online, vol. 9(1), pp. 1-16

Hernes, T. (2004). The Spatial Construction of Organization. Amsterdam: John Benjamins Publishing Company.

Holloway Cripps, K. G. (2013). Art Imitates Life: Art and Architecture as a Driving Force for Change. Journal of Organizational Change Management, vol. 26(1), pp. 4963. 
Kornberger, M. and Clegg, S. (2004): Bringing Space Back in. Organization Studies, vol. 25(7), pp. 1095-1114.

Lancione, M. and Clegg, S. (2013). The Chronotopes of Change: Actor-Networks in a Changing Business School. Journal of Change Management, vol. 13(2), pp. 117142.

Latour, B. (2003). What if We Talked Politics a Little?, Contemporary Political Theory, vol. 2(2), pp. 143-164.

Latour, B. (2013). An inquiry into modes of existence. Cambridge, Massachusetts: Harvard University Press.

Latour, B and Yaneva, A. (2008). Give Me a Gun and I Will Make All Buildings Move: An ANT's View on Architecture. I: Geiser, R. (red.) (2008). Explorations in Architecture: Teaching, Design, Research, pp. 80-89, Basel: Birkhauser.

Lefebvre, H. (1991). The production of Space, Oxford: Basil Blackwell.

Leonardi, P. M., and Barley, S. R. (2008). Materiality and Change: Challenges to Building Better Theory about Technology and Organizing. Information and organization, vol. 18(3), pp. 159-176.

Massey, D. (2005). For space. Thousand Oaks, California: Sage Publications.

Morgan, G. (2006). Images of Organization (updated edition). Thousand Oaks, California: Sage Publications.

Munro, I. and S. Jordan. (2013). Living Space at the Edinburgh Festival Fringe: Spatial Tactics and the Politics of Smooth Space. Human Relations, vol. 66(11), pp. 14971525.

Pink, S. (2007). Doing visual ethnography: Images, media and representation in research. London: Sage Publications.

Silverman, D. (1993), Interpreting Qualitative Data: Methods for Analysing Talk, Text and Interaction, London: Sage Publications.

Taylor, S. and Spicer, A. (2007). Time for Space: A Narrative Review of Research on Organizational Spaces. International Journal of Management Reviews, vol. 9(4), pp. 325-346.

Thomas, R., and Davies, A. (2005). Theorizing the Micro-politics of Resistance: New Public Management and Managerial Identities in the UK Public Services. Organization studies, vol. 26(5), pp. 683-706.

Thomas, R. and Hardy, C. (2011) Reframing Resistance to Organizational Change. Scandinavian Journal of Management, vol. 27, pp. 322-331.

Thomas, R., Sargent, L. D., and Hardy, C. (2011). Managing Organisational Change: Negotiating Meaning and Power-resistance Relations. Organisation Science, vol. 22(1), pp. 22-41.

Van Marrewijk, A. H. (2009). Corporate Headquarters as Physical Embodiments of Organizational Change. Journal of Organization Change Management, vol. 22(3), pp. 290-306.

Van Marrewijk, A. and Yanow, D (eds.) (2010). Organizational Spaces: Rematerializing the Workaday World. Cheltenham, UK: Edward Elgar. 
Våland, M. S and Georg, S. (2018) Spacing Identity: Unfolding Social and Spatial-material Entanglements of Identity Performance. Scandinavian Journal of Management, vol. 34, pp. 193-204.

Zhang, Z. and Spicer, A. (2013). 'Leader, you First': The Everyday Production of Hierarchical Space in a Chinese Bureaucracy. Human Relations, vol. 67(6), pp. 739762. 